\title{
Alaska's North Slope Borough Revisited
}

prepared for submission to Polar Record

\section{by}

Gunnar Knapp and Thomas A. Morehouse Institute of Social and Economic Research

University of Alaska Anchorage

3211 Providence Drive

Anchorage, Alaska 99508

(907) 786-7710

January 1991

This publication is printed on recycled paper. 


\begin{abstract}
Alaska's North Slope Borough, established in 1972, is in many ways a unique institution of Native-controlled local government in the north. The borough represents a significant case study of Native self-determination under unusually favorable conditions: indigenous, local control of both resource wealth and political power.

The North Slope Borough has been the instrument by which the Inupiat of the North Slope have successfully captured and used the oil wealth in their region, with clear economic and political benefits. They have gained high levels of local public services, jobs, and incomes; and effective representation in negotiations with external corporate and government authorities. The borough has also helped to preserve and adapt critical elements of traditional Inupiat culture.

Costs of development and change under North Slope Borough leadership have included waste and inefficiency as well as crime and corruption. Centralized power in borough headquarters has reduced the independence of the borough villages and encouraged borough citizens to act like clients and consumers. The Borough economy remains dependent upon uncertain tax revenues from the oil industry, with uncertain future employment opportunities for a rapidly growing Native population.

North Slope Borough government has provided the Alaska arctic Inupiat with means to greater political self-sufficiency. Overall, the North Slope Borough has responded effectively, under great pressure, to the opportunities and the problems that petroleum development has brought to the region.
\end{abstract}





\section{INTRODUCTION}

The North Slope of Alaska lies between the Brooks Range and the Arctic Ocean and covers an area of 228,800 square kilometers, 15 percent of the land area of the state. This region has a year-round resident population of 5,700 persons living in eight widely-separated villages. About 70 percent of these people are Inupiat Eskimos. Barrow, the largest village, has 3,400 residents, about 40 percent of whom are non-Inupiat. The remaining villages are almost exclusively Inupiat and range in size from less than 200 (Point Lay) to more than 500 (Point Hope and Wainwright).

Also located on the North Slope is the Prudhoe Bay oil field, the largest accumulation of petroleum ever discovered in North America. The field was brought into production in 1977 following completion of the Trans-Alaska Pipeline. In 1990 Prudhoe Bay and neighboring fields produced more than 1.7 million barrels of oil per day, or nearly a quarter of total U.S. oil production. About 5,500 workers are employed in these fields, and almost all of them are temporary residents of camp facilities located on the oil fields.

In 1972, the people of the eight North Slope villages voted to establish a borough, a form of local or regional government similar to a county elsewhere in the United States. The North Slope Borough covers the whole region, and after overcoming political and legal challenges to its incorporation and to its tax powers, the borough began collecting property taxes from oil field developments. Within a few years, the North Slope Borough became one of the richest local and regional governments in the United States as measured by taxable wealth and tax revenues per capita.

When the borough was formed, there were few jobs in the villages, public facilities were minimal, and living standards were low. Barrow, for example, had no high school, and no privately-owned homes had piped water or sewer systems. Conditions in the smaller villages were worse. Since that time, borough spending for operations and capital construction projects has provided dramatically higher employment and incomes in all the villages, as well as a broad array of public services and facilities.

In a 1980 Polar Record article, "Alaska's North Slope Borough: Oil, Money, and Eskimo Self-Government," Morehouse and Leask reviewed the development of the borough during the 
seven years from its establishment in 1972 through 1979. They found that the borough had brought greater self-government and substantial economic benefits to the North Slope Inupiat, but also that the Inupiat people had become increasingly dependent on oil development and the cash economy and that their culture was undergoing rapid and uncertain change. The authors concluded that the greatest long term threat to the borough was the inevitable decline and depletion of the Prudhoe Bay oil field, with "insufficient alternative sources of either local tax revenues or private income to maintain living standards now assured by borough facilities, services and employment." They also pointed out that the borough remained "vulnerable to legal and political challenges to its claims on the resource wealth of the region."

In this article we review the further development of the borough since 1979. Given its authority to tax high-value oil field properties, the North Slope Borough is in many ways a unique institution of Native-controlled local government in the north. At the same time, however, the borough represents a significant case study of Native self-determination under unusually favorable conditions: indigenous, local control of both resource wealth and political power. In the following sections we review the evolution of North Slope Borough government, economic development and social welfare in the region's villages, and Inupiat cultural and political change. We conclude with some general observations on the overall performance and the future prospects of the borough.

\section{EVOLUTION OF THE BOROUGH}

Inupiat leaders on Alaska's North Slope began planning for the incorporation of the borough soon after the Atlantic Richfield Company announced the discovery of massive oil deposits at Prudhoe Bay in 1968 (McBeath 1980: 10-14). They realized that with borough powers of taxation and regulation, North Slope Natives could both capture substantial resource wealth for local use and help protect their subsistence resource environment. Two years earlier, Inupiat leaders had organized the Arctic Slope Native Association (ASNA) to pursue Native land claims as part of a statewide Native political movement. Now the ASNA would pursue borough incorporation as well, which would ensure even greater control of land, resources, and local political institutions in their region than even the most favorable land claims settlement seemed likely to do. 
North Slope Natives' share of the 44 million acre, $\$ 1$ billion Alaska Native Claims Settlement Act of 1971 was about 5 million acres and $\$ 52$ million (Arnold 1976). The land transferred to the Arctic Slope Regional Corporation and the eight village corporations created by the act represented less than 10 percent of the total North Slope region that had been claimed by the ASNA. For this reason, the ASNA was the only Native regional association to vote against accepting the claims settlement act passed by Congress. ASNA leaders wanted the settlement to comprise a lot more land, including more North Slope lands with oil potential.

Incorporating the borough provided an opportunity to compensate in some part for the lands and resources that Inupiat leaders felt they had lost in the Congressional settlement, which they had to accept. State law had authorized broad property tax powers for all boroughs. Thus, it appeared to Native leaders that a borough's property tax power would extend to the oil lands at Prudhoe Bay, even though those lands had been transferred by the federal government to the State of Alaska--as part of its statehood land entitlement-- several years before the oil discovery. Prudhoe Bay and other North Slope oil lands were owned by the state and leased to the oil companies, but borough taxing and land use regulatory powers over those same lands provided the Inupiat residents of the area with means of sharing directly in the wealth as well as moderating the environmental impacts of oil development.

The State of Alaska and the oil companies viewed the situation differently. They asked why a few thousand residents of this remote region should be permitted exclusive powers of local property taxation over the largest property tax base in the state outside of Anchorage. Borough property taxes on the multi-billion dollar facilities used to produce and transport oil would yield many times more income to North Slope Natives than they would ever obtain under the terms of the 1971 claims settlement act. Borough incorporation was like a second settlement act specifically for the North Slope, an unplanned settlement due solely to the fortuitous location of a huge oil reservoir.

The state government administration at first resisted incorporation of a borough government that could tax North Slope oilfield property. The governor believed that the super-giant field at Prudhoe Bay was a statewide resource, and that tax revenues from oilfield installations as well as from the oil itself should be collected by state government for use throughout the whole state. Instead of explicitly opposing the incorporation, however, the state 
administration persuaded the legislature in 1973 to enact a statewide tax on petroleum production and transport (primarily pipeline) facilities and to limit local taxing powers. Further, the state permitted the oil companies to deduct from their state property tax bill the full amount of local property taxes on oil field and transport facilities.

The oil companies challenged the existence of the North Slope Borough in state courts immediately following its incorporation in 1972. State law, however, clearly supported the creation of boroughs throughout the state, including a region like the North Slope, and in 1973 the Alaska Supreme Court ruled that the incorporation was constitutional. A few years later the companies again challenged the borough, this time on the extent of its property tax powers. The borough held that it could tax, beyond the state-imposed limit, for purposes of paying debt service on its capital construction bonds, and the Supreme Court upheld the borough's position. This was a particularly significant victory for the North Slope Borough. It had already launched what would eventually become a billion dollar capital construction program, a program financed primarily through bonds secured by the oilfield property tax base.

\section{ECONOMIC DEVELOPMENT}

Within a few years of its establishment, the borough was collecting and spending tens of millions of dollars annually on a capital improvements program (CIP) that was bringing schools, community halls, water and sanitation facilities, public health programs, and other amenities to North Slope villages. The CIP and an expanding borough administrative bureaucracy also provided jobs to the majority of the region's indigenous work force as well as to an increasing number of immigrants. The residents of the borough enjoyed virtually a full employment economy during the 1980s. Certainly, one of the original goals of borough incorporation--to improve the material welfare of North Slope residents--was being achieved.

The borough's wealth has not created new economic activity in the borough villages other than that directly supported by borough spending. Towards the end of the 1980s, after a period of rapid growth, the borough's tax base, revenues and expenditures peaked and then began to gradually decline. With a rapidly rising population, the borough is likely to soon face the challenge predicted by Morehouse and Leask of maintaining the living standards achieved over the past decade. 
The foundation of the borough's economy is the tax base provided by the oil industry. Between 1977 and 1987 the total assessed value of the borough rose from $\$ 1.8$ billion to $\$ 13.6$ billion, more than 98 percent of which consisted of oil industry property (Table 1). With 1.4 percent of Alaska's resident population, in 1989 the borough accounted for 70 percent of the state's oil and gas property value and 30 percent of the state's total property value. The borough's per capita property value was thirty times as high as for the rest of the state (Department of Community and Regional Affairs 1990).

Between 1977 and 1987, annual borough property tax revenues increased from $\$ 19$ million to a peak of $\$ 249$ million. The increase in property taxes was based not only on an expanding tax base but also on an increase in the tax rate from to 1.03 percent to 1.84 percent. Property taxes of $\$ 228$ million accounted for 72 percent of total borough revenues in 1989 .

After 1982, interest earnings on the borough's cash holdings from taxes and bond sales represented another major source of income. In 1989, the borough's cash holdings of more than $\$ 700$ million earned $\$ 45$ million in interest, which represented 14 percent of borough revenues. Other borough revenues, primarily state assistance for education and school construction, grew rapidly during the early 1980 's, peaking at $\$ 105$ million in 1985 , and declined to $\$ 45$ million in 1989 , or 14 percent of borough revenues.

Soon after its establishment, the borough began selling bonds to finance an ambitious capital improvements program (CIP). The borough's net bonded debt increased rapidly, reaching a peak of $\$ 1.2$ billion in 1984. In subsequent years, debt repayment exceeded bond sales, and the borough's debt declined to $\$ 736$ million in 1989. In 1986, North Slope Borough debt accounted for 40 percent of total public debt in Alaska, and the borough's per capita debt of $\$ 266$ thousand exceeded that of the state as a whole by 44 times.

During the borough's first decade, revenues and bond sales permitted a dramatic expansion of both capital and operating expenditures. Between 1977 and 1983, capital expenditures increased from $\$ 14$ million to a peak of $\$ 302$ million, while operating expenditures increased from $\$ 18$ million to $\$ 69$ million. After 1983, capital expenditures declined sharply to an average of $\$ 75$ million for the years 1987-89. Operating expenditures continued to grow, although much more slowly, to about $\$ 100$ million in 1989. 
Table 1: North Slope Borough Property Values, Revenues, Debt and Expenditures, fiscal Years 1977-89

\begin{tabular}{|c|c|c|c|c|c|c|c|c|c|c|c|}
\hline \multirow[b]{2}{*}{$\begin{array}{l}\text { Fiscal } \\
\text { Year }\end{array}$} & \multicolumn{2}{|c|}{ PROPERTY VALUE } & \multicolumn{4}{|c|}{ REVENUES } & \multicolumn{2}{|c|}{ DEBT } & \multicolumn{3}{|c|}{ EXPENDI TURES } \\
\hline & $\begin{array}{c}\text { Assessed } \\
\text { Property } \\
\text { Value } \\
\text { (\$ billions) }\end{array}$ & $\begin{array}{c}\text { Effective } \\
\text { Tax } \\
\text { Rate } \\
\text { (percent) }\end{array}$ & $\begin{array}{l}\text { Total } \\
\text { Property } \\
\text { Taxes } \\
---.-\end{array}$ & $\begin{array}{l}\text { Interest } \\
\text { Income } \\
- \text { - } \$ \text { mill }\end{array}$ & $\begin{array}{c}\text { Other } \\
\text { (ncome(a) } \\
\text { (ions)- - }\end{array}$ & $\begin{array}{c}\text { Total } \\
\text { Revenues } \\
----\end{array}$ & $\begin{array}{l}\text { Net } \\
\text { Bonded } \\
\text { Debt } \\
-(\$ \mathrm{mil} !\end{array}$ & $\begin{array}{l}\text { Increase } \\
\text { in Net } \\
\text { Bonded } \\
\text { Debt } \\
\text { (ions)- - }\end{array}$ & $\begin{array}{l}\text { Operations } \\
-\ldots .-(\$\end{array}$ & $\begin{array}{c}\text { Capital } \\
\text { Improvements } \\
\text { Program } \\
\text { mil(ions)- - }\end{array}$ & $\begin{array}{l}\text { Debt } \\
\text { Service } \\
\because .\end{array}$ \\
\hline 1977 & 1.8 & 1.03 & 19 & 1 & 9 & 30 & 83 & NA & 18 & 14 & 4 \\
\hline 1978 & 3.6 & 0.75 & 27 & 5 & 14 & 46 & 77 & -6 & 25 & 35 & 5 \\
\hline 1979 & 4.7 & 0.73 & 36 & 7 & 18 & 60 & 198 & 121 & 30 & 72 & 15 \\
\hline 1980 & 5.0 & 1.04 & 52 & 7 & 20 & 80 & 254 & 56 & 40 & 93 & 26 \\
\hline 1981 & 5.7 & 1.03 & 59 & 9 & 47 & 114 & 454 & 200 & 50 & 131 & 36 \\
\hline 1982 & 6.6 & 1.67 & 110 & 44 & 43 & 197 & 580 & 126 & 64 & 211 & 68 \\
\hline 1983 & 8.2 & 1.64 & 134 & 44 & 50 & 228 & 742 & 162 & 69 & 302 & 95 \\
\hline 1984 & 10.0 & 1.53 & 152 & 59 & 56 & 267 & 1205 & 463 & 79 & 211 & 130 \\
\hline 1985 & 12.3 & 1.84 & 228 & 45 & 105 & 377 & 1169 & -36 & 90 & 111 & 178 \\
\hline 1986 & 12.8 & 1.84 & 236 & 45 & 87 & 368 & 1079 & -90 & 92 & 57 & 184 \\
\hline 1987 & 13.6 & 1.84 & 249 & NA & NA & 347 & 936 & -143 & 99 & 75 & 196 \\
\hline 1988 & 12.6 & 1.84 & 236 & 45 & 25 & 306 & 842 & -94 & 101 & 78 & 203 \\
\hline 1989 & 11.9 & 1.84 & 228 & 45 & 45 & 318 & 736 & -106 & 102 & 73 & 197 \\
\hline
\end{tabular}

NA: Not available

(a) Primarily intergovernmental transfers. Calculated as total income minus property taxes and interest income.

Sources: North Slope Borough, Comprehensive Annual Financial Reports, FY86-FY89. North Slope Borough, Budget Documents, FY75-FY86. 
Most of the borough's capital expenditures have been for schools, roads, housing, water facilities and sewage facilities. Among the most expensive of the hundreds of projects were a $\$ 70$ million high school in Barrow and a more than $\$ 200$ million water and sewer system for Barrow.

In 1977, more than half of the borough's operating expenditures were for education (table 2). As operating expenditures have increased, the share allocated to education has declined to 29 percent. Between 1984 and 1989, total expenditures for education, municipal services and housing grew only slightly, from $\$ 48.1$ million to $\$ 51.5$ million, while expenditures for other services including general government, public safety, and health and social services, increased rapidly from $\$ 30.4$ million to $\$ 50.9$ million.

In addition to providing vastly improved public facilities and services, borough spending has created jobs and income for North Slope Borough residents. Surveys conducted in 1980 and 1988 show that employment in the borough's villages increased by about 50 percent during the 1980's (Table 3). In both 1980 and 1988, government jobs accounted for about two-thirds of all employment. These jobs represented almost the entire economic base of the villages. Almost all private employment consisted of support activities such as communications, trade and services. In 1988, private employment in basic industries--mining and fishing--was estimated at 51 , only 3 percent of total employment. Native corporation employment, estimated at 311 , or 12 percent of total employment, may have included some additional basic employment.

There are several differences in employment patterns between Natives and non-Natives. The North Slope Borough School District accounted for 12 percent of Native employment, compared with 23 percent of non-Native employment. Native corporations accounted for 17 percent of Native employment compared with 5 percent of non-Native employment.

The employment rate of working-age Natives increased from 57 percent in 1980 to 74 percent in 1988 (table 4). Almost all working-age non-Natives are employed.

The North Slope Borough reported that "between 1980 and 1988, ... the rate of unemployment ... fell from 24 percent to 5.2 percent for all eight NSB traditional communities. This rate of unemployment is probably the single most important measure of economic success ... (and) suggests that the NSB economy experienced substantial gains during the 1980s" (Nebesky 1989: III-15). 
Table 2: North slope Borough operating Expenditures, Fiscal Years 1977-89

\begin{tabular}{|c|c|c|c|c|c|}
\hline & 1977 & 1980 & 1983 & 1986 & 1989 \\
\hline EXPENDITURES ( $\$$ MILLIONS) & 18.1 & 39.7 & 68.8 & 92.3 & 102.4 \\
\hline $\begin{array}{l}\text { General government } \\
\text { Public safety } \\
\text { Municipal services (a) } \\
\text { Housing } \\
\text { Health and social services } \\
\text { Education } \\
\text { Other } \\
=========================\end{array}$ & $\begin{array}{r}3.0 \\
0.6 \\
2.9 \\
0.0 \\
0.6 \\
10.0 \\
1.0 \\
======\end{array}$ & $\begin{array}{r}7.7 \\
3.2 \\
8.0 \\
1.0 \\
2.4 \\
16.4 \\
1.1 \\
=====\end{array}$ & $\begin{array}{r}14.9 \\
5.6 \\
13.9 \\
4.8 \\
5.4 \\
22.7 \\
1.5 \\
=======\end{array}$ & $\begin{array}{r}20.2 \\
7.8 \\
18.5 \\
5.7 \\
7.3 \\
30.4 \\
2.4 \\
=====\end{array}$ & $\begin{array}{r}28.7 \\
8.2 \\
16.6 \\
5.5 \\
11.9 \\
29.4 \\
2.1 \\
=====\end{array}$ \\
\hline $\begin{array}{l}\text { PERCENT OF TOTAL } \\
\end{array}$ & & & & & \\
\hline General government & 17 & 19 & 22 & 22 & 28 \\
\hline Public safety & 3 & 8 & 8 & 8 & 8 \\
\hline Municipal services (a) & 16 & 20 & 20 & 20 & 16 \\
\hline Housing & 0 & 3 & 7 & 6 & 5 \\
\hline Health and social services & 3 & 6 & 8 & 8 & 12 \\
\hline Education & 55 & 41 & 33 & 33 & 29 \\
\hline other & 5 & 3 & 2 & 3 & 2 \\
\hline
\end{tabular}

(a) Public works and public utilities.

Source: North Slope Borough 1987: 114, 115; North Slope Borough 1990: 128, 129 . 
Table 3: North Slope Borough Employment, by Race, 1980 and 1988

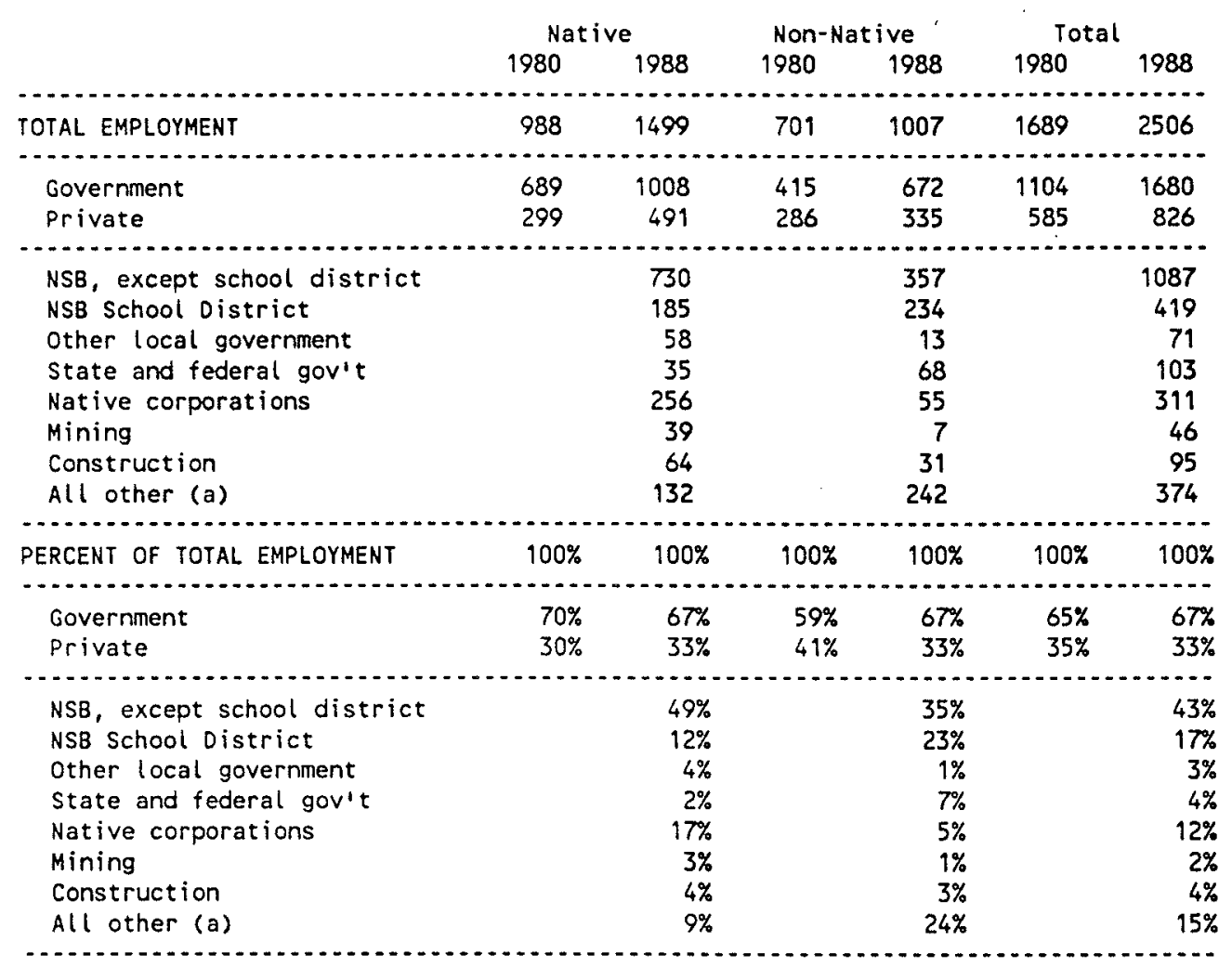

(a) Includes primarily support activities such as transportation, communications, public utilities, trade, and services.

Sources: Nebesky 1989: II I-9; North Slope Borough Housing Survey, 1980, as reported in Impact Assessment, Inc. 1990: NSB-54. 
Table 4: North Slope Borough Working Age Population and Employment, by Race, 1980 and 1988 (a)

\begin{tabular}{|c|c|c|c|c|c|c|}
\hline & \multicolumn{2}{|c|}{ Native } & \multicolumn{2}{|c|}{ Non-Native } & \multicolumn{2}{|c|}{ Total } \\
\hline & 1980 & 1988 & 1980 & 1988 & 1980 & 1988 \\
\hline Total population (b) & 3086 & 3851 & 802 & 1498 & 3888 & 5349 \\
\hline Working age population (c) & 1740 & 2028 & 637 & 1084 & 2377 & 3112 \\
\hline $\begin{array}{l}\text { Working age population } \\
\text { as share of total population }\end{array}$ & $56 \%$ & $53 \%$ & $79 \%$ & $72 \%$ & $61 \%$ & $58 \%$ \\
\hline Total employment & 988 & 1499 & 701 & 1007 & 1689 & 2506 \\
\hline $\begin{array}{l}\text { Total employment as share of } \\
\text { working age population }\end{array}$ & $57 \%$ & $74 \%$ & $110 \%$ & $93 \%$ & $71 \%$ & $81 \%$ \\
\hline
\end{tabular}

(a) Survey methodologies differed between 1980 and 1988 . Thus data are not precisely comparable.

(b) Excludes 254 persons in 1980 and 318 persons in 1988 for whom race, age or sex was not known.

(c) Includes persons between the ages of 18 and 65 .

Sources: Nebesky 1989: 111-3, 9, 11, 17; North Slope Borough Housing Survey, 1980, as reported in Impact Assessment, InC. 1990: NSB-9, 54. 
However, the relative prosperity of the North Slope Borough may have peaked. Some researchers have suggested that the borough's official unemployment figures are inflated by counting short-term and part-time jobs, and suggest that "according to individual informant accounts there is actually a very high rate of unemployment in the villages" (Impact Assessment 1990: NSB-72). In recent years, the availability of high-paying construction jobs has declined significantly as CIP expenditures have fallen. Providing jobs was a major reason for undertaking many CIP projects. The Borough directly hired residents to work on projects at high wages, and tended to overlook absenteeism and other problems in order to hire as many residents as possible.

Many current lower-level borough positions are not as attractive. According to a recent survey, a common perception was that these jobs "were not very desirable and that the pay was low... The legacy of the old CIP program, where many people were paid regardless of the quality of their work, is ... still cited as a contributory factor to the relatively irregular work habits of a significant portion of the work force" (Impact Assessment 1990: NSB-73).

Economic prosperity is not equally shared by all households. In 1988, 28 percent of Native households had household incomes of less than $\$ 20,000$, while one-fifth of Native households had incomes exceeding $\$ 60,000$ (table 5). More than half of all non-Native households had household incomes exceeding $\$ 60,000$.

Borough debt service expenditures have risen rapidly as total debt has increased, and have accounted for an increasingly large share of borough revenues. Debt service expenditures now account for more than half of all borough expenditures. However, debt service expenditures are projected to decline substantially during the next decade as current debt is repaid.

Borough property values peaked at $\$ 13.6$ billion in 1987 and declined to $\$ 11.8$ billion in 1990. Property values are projected to increase again in the early 1990's as a result of additional development investments, but subsequently to decline as a result of the projected 10 percent per year decline in oil production as the Prudhoe Bay field is exhausted. According to an Alaska Department of Revenue "mid-range" projection, the North Slope Borough property value will be $\$ 9.1$ billion in 2000 . The "conservative" projection is for a value of $\$ 6.1$ billion-still a very large figure. It is difficult to project how property values may change in the more 
Table 5: North Slope Borough Household Incone Distribution, by Race, 1988

Native
Average household income
Household income category
Under $\$ 20,000$

Source: Nebesky 1989: 111-11. 
distant future. Because of additional investments in secondary and tertiary recovery projects, oil property values may not decline as rapidly as oil production. Development of known deposits such as the huge Ugnu formation or the potential discoveries in the Arctic National Wildlife Refuge could lead to large-scale new oil development projects. In any case, it seems likely that for at least the next decade, the borough will continue to enjoy a very large property tax base.

Even if property values do not decline, it is uncertain whether borough spending can continue to keep pace with population growth in maintaining Native employment and income. The borough's Native population increased by 26 percent between 1980 and 1988, for an annual growth rate of 2.9 percent (table 6). During the same period, total borough operating and capital expenditures increased by about 32 percent (table 1). However, growth in borough spending ended in 1987; over the past three years, borough revenue and spending have been stable. In 1988, 43 percent of the Native population was under the age of 18 (Nebesky 1989: III-3). It will be difficult to increase government spending enough to create sufficient employment for these younger Natives as they enter the labor force.

In 1988, non-Natives held more than 40 percent of all jobs in the borough villages (table 3). Increasing the share of jobs held by Natives could provide a mechanism for increasing Native employment. However, many of the jobs primarily held by non-Natives, such as teaching jobs, require training and certification which are obtained by relatively few Natives. In addition, there are constitutional limits to preferential hiring of Natives; it is possible that competition from non-Natives could cause the Native share of employment to decline.

Development of a self-supporting economic base has always been a stated goal of the North Slope Borough. In 1983, then-borough mayor Brower wrote: "when the oil companies leave the Arctic, they will leave American communities fully developed and self-supporting, all along Alaska's Arctic coast..." (North Slope Borough 1983). However, as employment data make clear, no economic development has yet occurred in the North Slope Borough villages which would in any sense make the borough economically independent of the oil industry tax base. 
Table 6: North slope Borough Resident Population, by Race, 1980 and 1988

\begin{tabular}{|c|c|c|c|c|}
\hline & & Barrow & $\begin{array}{c}\text { Other } \\
\text { villages }\end{array}$ & Total \\
\hline $\begin{array}{l}\text { NATIVE } \\
\text { POPULATION }\end{array}$ & $\begin{array}{l}1980 \\
1988 \\
\text { Change }\end{array}$ & $\begin{array}{l}1720 \\
2040 \\
19 \%\end{array}$ & $\begin{array}{l}1488 \\
2010 \\
35 \%\end{array}$ & $\begin{array}{l}3208 \\
4050 \\
26 \%\end{array}$ \\
\hline $\begin{array}{l}\text { NON-NATIVE } \\
\text { POPULATION }\end{array}$ & $\begin{array}{l}1980 \\
1988 \\
\text { Change }\end{array}$ & $\begin{array}{c}487 \\
1331 \\
173 \%\end{array}$ & $\begin{array}{l}132 \\
286 \\
117 \%\end{array}$ & $\begin{array}{c}619 \\
1617 \\
161 \%\end{array}$ \\
\hline $\begin{array}{l}\text { POTAL } \\
\text { POPULATION }\end{array}$ & $\begin{array}{l}1980 \\
1988 \\
\text { Change }\end{array}$ & $\begin{array}{r}2207 \\
3371 \\
53 \%\end{array}$ & $\begin{array}{r}1620 \\
2296 \\
42 \%\end{array}$ & $\begin{array}{r}3827 \\
5667 \\
48 \%\end{array}$ \\
\hline $\begin{array}{l}\text { NATIVE SHARE } \\
\text { OF POPULATION }\end{array}$ & $\begin{array}{l}1980 \\
1988\end{array}$ & $\begin{array}{l}78 \% \\
61 \%\end{array}$ & $\begin{array}{l}92 \% \\
88 \%\end{array}$ & $\begin{array}{l}84 \% \\
71 \%\end{array}$ \\
\hline $\begin{array}{l}\text { SHARE OF TOTAL } \\
\text { POPULATION }\end{array}$ & $\begin{array}{l}1980 \\
1988\end{array}$ & $\begin{array}{l}58 \% \\
59 \%\end{array}$ & $\begin{array}{l}42 \% \\
41 \%\end{array}$ & $\begin{array}{l}100 \% \\
100 \%\end{array}$ \\
\hline
\end{tabular}




\section{ADMINISTRATIVE AND POLITICAL PROBLEMS}

The most difficult problems the borough faced during the 1980s stemmed largely from the rapid rate of growth and the magnitude of its operations and particularly of its capital construction program. The borough's administrative and political capacities, limited from the start, were soon overextended. Indigenous North Slope leaders had to import non-Native managers and professionals to operate the borough administration. They also needed to hire consultants capable of quickly assembling manpower and materials and striking multi-million dollar deals with bond underwriters and suppliers.

The fast pace of the capital construction program appears to have been driven largely by perceived threats to the borough's tax power in the state legislature, and borough officials as well as consultants and contractors seemed to believe it was in their and the borough's interests to raise and spend capital funds as quickly as possible (Chance 1990: 183-186). The borough's Native leaders faced classic managerial problems of planning, control, and coordination for which they were not prepared. Consequently, they depended on others to provide a large part of the operational expertise, and they trusted their consultants to help them make the right operational decisions. These managerial weaknesses made the borough vulnerable to financial corruption and scandal.

By October 1984, when George Ahmoagak was elected borough mayor, there were clear signs of trouble. The borough was paying huge sums of money to outside contractors, consultants were making basic decisions about borough hiring and spending, and administrative systems to control and account for these decisions and operations were inadequate. Ahmoagak ran for mayor on a platform responsive to these concerns: he promised to get control of consultants and "runaway spending," require more competitive bidding for contracts, redirect more business to village corporations, and increase local resident hire in the construction program (Associated Press 1984). Shortly after his election, he ordered an audit of the borough's finances, fired key consultants, and initiated administrative reforms.

Federal authorities also became interested in the borough's finances after Ahmoagak's election. An FBI investigation led to charges of bribery, fraud, tax evasion, and other crimes against some two dozen individuals, including consultants, contractors, and borough officials. Two key consultants were convicted of over twenty counts of racketeering, conspiracy, 
extortion, mail and wire fraud, and travel act violations. Most of the others involved pleaded guilty to lesser charges of tax evasion, bribery, and concealment of felonies. Eugene Brower, the borough mayor who preceded Ahmoagak, and his public works director pleaded guilty to tax evasion and testified for the prosecution (Mauer 1990).

The corruption scandal was severe shock but not a disaster for the North Slope Borough. Only a few of its officials were directly implicated, and they were forced from office even before their part in the scandal had been fully exposed. Mayor Ahmoagak led the initial investigation, and he reformed the administration of the capital improvements program. Consistent with his campaign promises, he redirected the program toward construction of basic facilities, increased village hire, and more contracting with local businesses.

By the end of Ahmoagak's second term in 1990, the borough had renewed its commitment to the original goals of incorporation: development of the North Slope economy, improvement of social welfare, protection of the subsistence environment, preservation of the Inupiat culture, and strengthening of Inupiat self-government.

\section{CULTURAL AND POLITICAL CHANGE}

The borough's basic policies concerning environmental protection and subsistence resource management were formed in the late 1970s. During that period, the borough claimed decisionmaking authority in the regulation of caribou hunting, the taking of whales, and the development of onshore and offshore petroleum resources (Morehouse, McBeath and Leask 1984: 151-155). State, national, and international regulatory bodies resisted the claims of the upstart borough. The borough nonetheless made significant inroads into management areas that were formerly the exclusive province of superior government authorities (Chance 1990: 175-178).

North Slope Borough leaders have aggressively asserted the borough's regulatory powers while recognizing the real political and legal limits on local government authority. They have also recognized the necessity for negotiation, bargaining, and compromise with external agencies. In pursuit of conflicting interests in development and preservation, borough leaders have attempted to protect the traditional Inupiat subsistence culture by playing a modern American game of politics. 
At the same time that borough leaders have asserted their regulatory powers, they have supported petroleum development on the North Slope. Testifying before a Congressional committee on Alaska lands legislation in 1977, Mayor Eben Hopson acknowledged the conflicting interests underlying the borough's position. He proposed that, except for village lands granted to Native corporations under the Native claims settlement act, the entire North Slope should be classified "as a wildlife range reserve allowing as the only human activities those associated with natural resource extraction and traditional subsistence gathering" (Morehouse and Leask 1978: 51).

There was little the borough could do to influence development of the huge Prudhoe Bay complex, which was already well underway by the time the borough was capable of enforcing local regulatory authority in the mid-1970s. However, neither Hopson nor subsequent leaders ever sought to stop or delay the development of the Prudhoe Bay field itself. It was clear that the borough's greatest economic returns would come from extensive development of taxable oil field properties. Further, the borough increased its stake in the expansion and operation of the North Slope fields by creating a service area in the Prudhoe Bay industrial area and selling public utility services to the industry.

The borough has vigorously opposed oil development elsewhere in the arctic, however. Borough leaders determined that their main environmental concerns were not with relatively safe and mostly isolated onshore field activities, but with oil and gas drilling on the offshore outer continental shelf (OCS), which also happened to lie largely beyond the reach of their taxing authority. Mayor Hopson made a political crusade of his opposition to oil development on the OCS after he learned about the Dome Oil (water) blowout in the MacKenzie Delta of Canada's Northwest Territories in 1976. Opposition to state and federal leasing on the OCS was in fact one of the primary motivations behind the borough's 1977 initiative to establish the Inuit Circumpolar Conference, an international association of Native leaders from Alaska, Canada, and Greenland, which has focused on arctic environmental concerns.

Hopson and his advisors believed that oil drilling and pipeline technology were unreliable especially where offshore pack ice was involved. Borough leaders have consistently opposed offshore OCS drilling while reluctantly agreeing to nearshore developments where measures could be taken to protect migrating bowhead whales and other subsistence resources. Since the 
late 1970s, the borough has lost several court challenges to state and federal OCS leasing actions. Although the borough has not been able to stop offshore leasing, it has been more successful in using its regulatory powers to specify terms and conditions of development where important subsistence resources may be threatened.

Borough leaders have been much more receptive to petroleum development in onshore areas in addition to Prudhoe Bay. This includes the proposed exploration of the coastal plain of the Arctic National Wildlife Refuge, which geologists believe may hold several billion barrels of oil. The area also includes seasonal rangeland and calving grounds of the Porcupine caribou herd, on which Alaskan and Canadian Native villagers depend for subsistence. Environmental organizations, non-Inupiat Native groups, and the Canadian government oppose opening the refuge to development because of the threat to the herd and their habitat. Although some North Slope villagers near the refuge oppose drilling, most other villagers appear to support the borough's position that exploration and development can occur without significantly harming the herd (Impact Assessment, Inc. 1990: 168).

In general, villagers as well as borough leaders are aware of their dependence on continuation of the North Slope oil economy. While villagers want to protect subsistence resources, they also want access to the jobs and incomes that oil brings, primarily through borough employment. Having shared the North Slope with the oil industry for a generation or more, villagers generally seem to believe today, as Mayor Hopson did in the 1970s, that resource development and subsistence living can be compatible activities. Reflecting this attitude as well as the interests of his organization, the president of the Arctic Slope Regional Corporation recently stated that he was "prepared to take the measures required to protect the Arctic environment--animal and human alike--from the risks posed by oil development. But I am not prepared to forfeit rational social, economic, energy and environmental policy to those who are bent on 'protecting' something they have not seen and do not understand" (Adams 1990).

Surveys of villagers' subsistence activities in 1977 and 1988 lend support to the argument that North Slope development and subsistence have been compatible during the 1980s. According to Kruse, forty-nine percent of village households in 1988, compared to forty-five percent in 1977, reported that they received half or more of their food from subsistence activities. In addition, the higher the household income--meaning greater participation in the petroleum- based 
cash economy--the more likely was the family to obtain most of its food from subsistence (Kruse 1990). Thus, not only has the level of villagers' subsistence activities been maintained, but increased cash incomes appear to be related to greater involvement in subsistence hunting, fishing, and gathering activities.

Some observers have suggested that wage labor, which limits the time devoted to subsistence activities, has provided the incomes necessary to concentrate on higher priced subsistence resources, such as whales, caribou, and furbearers, as opposed to fish and seals (Impact Assessment, Inc. 1990: 166-167). The North Slope Borough has reinforced this preference by providing financial, technical, and political support to Inupiat whalers. The borough's Department of Wildlife Management devotes most of its considerable budget to whaling studies, which focus on the bowhead whale and its Arctic Ocean habitat.

In 1977 the International Whaling Commission (IWC) proposed a moratorium on harvests of bowhead whales, including subsistence harvests. The North Slope Borough responded to this threat to subsistence whaling by establishing the Alaska Eskimo Whaling Commission (AEWC), which represents whaling captains and crews from Inupiat villages. Supported by the borough, the AEWC cooperated with U.S. authorities in obtaining special subsistence quotas of bowheads from the IWC, and the borough has continued to assist the AEWC in allocating and enforcing the quotas among Inupiat whalers. The AEWC has become an international model of a successful "co-management" scheme (Osherenko 1987), where Native hunters share regulatory power with external governmental authorities, and the borough's support of the AEWC has been an essential factor in that success (Case 1989: 1030-1032).

Borough leaders have also been aware that their effectiveness in national and international political forums may be influenced by popular perceptions of their commitment to resource and habitat preservation even while they depend on the continuing development of the North Slope petroleum economy. When three gray whales migrating south for the winter were trapped in the ice off Barrow in October 1988, North Slope Natives had the opportunity to dramatize their commitment to resource preservation as leading players in a three-week media event that fascinated a world-wide audience of television viewers and newspaper readers. The "Great Whale Rescue" culminated in a successful effort by two Soviet icebreakers to free two of the whales from their immediate predicament. The borough's contribution to the event was primarily 
through its Department of Search and Rescue, which mobilized rescue volunteers and continuously shuttled representatives of the media and local, state, and federal officials between Barrow and the rescue site twelve miles out on the arctic ice.

Of course, the borough's commitment to the preservation of Inupiat culture is more than a public display. In addition to sponsoring the environmental and subsistence activities of the Inuit Circumpolar Conference, the AEWC, and its own Department of Wildlife Management, the borough also supports other aspects of traditional Inupiat culture through a Commission on History, Language, and Culture. The Commission sponsors Inupiaq language programs in village schools, an Inupiat elders program, and cultural events such as the annual Messenger Feast. Through these and other means, the borough has become the institutional center and custodian of Inupiat culture on the North Slope.

That Inupiat cultural identity has been reinforced through North Slope Borough government nonetheless suggests a contradiction that was reflected in the whale rescue: A westernized and politically sophisticated local government has used the wealth derived from large-scale petroleum development to support programs for preserving language, subsistence, and other elements of traditional culture. In the process, old ideas and practices have been revived and transformed and new ones introduced within an imported framework of western organization and technology. The borough has thus become not only the patron and organizer of Inupiat cultural programs but also the institutional base for reforming and modernizing the culture.

North Slope Borough government itself embodies tensions between village political cultures on the one hand and centralized bureaucracy and politics on the other. The borough was created not only to collect and distribute petroleum wealth but also to increase local, including village, self-government. From the start, however, borough leaders have centralized policymaking and administration at NSB headquarters in Barrow, and within the borough structure, powers have been concentrated in the office of the mayor. Early in his first term, Mayor Hopson persuaded the villages to transfer virtually all of their local government functions, including taxation, law enforcement, and utilities, to the borough. He argued that the borough would be a more efficient and effective government. Perhaps a more compelling point 
was that the borough controlled the revenues that would support an unprecedented array of facilities and services in all of the villages.

In the years since, Hopson's successors have completed the transfer of economic and political power to the borough level through control of service delivery, capital projects, jobs, and incomes. Recently, the consolidation of the Departments of Public Works and Utilities into a single Department of Municipal Services further concentrated borough authority for the construction and operation of public facilities. Similar centralization has occurred in borough health, fire and police, roads, and housing programs (Impact Assessment, Inc. 1990: 152-158). The public school system, too, is largely under the control of a Barrow-centered regional school board and administration (Impact Assessment, Inc. 1990: 163-164). The school system, in turn, depends more than any other Alaska school district on financial support that it obtains locally, in this case from the North Slope Borough.

Native governments in the form of federally-recognized Indian Reorganization Act (IRA) governments and traditional councils still exist in several villages, as do the shells of municipal (second-class city) governments and the village corporations established by the Alaska Native Claims Settlement Act. All of these village institutions, however, are politically and economically dependent on the borough and on decisions made in Barrow. The borough assembly nominally represents all North Slope villages, but at-large elections have regularly resulted in all but one or two of seven seats being held by residents of Barrow. Moreover, given the executive-centered nature of North Slope Borough government, the office of the mayor has for the most part dominated the borough assembly through control of the local policy agenda and the resources necessary to implement it (Morehouse, McBeath and Leask 1984: 143-146).

In the absence of an independent assembly or effective political organizations at the village level, the Arctic Slope Regional Corporation (ASRC) has been the main check within the region on the power of the borough mayor. ASRC's leaders have been active members of the borough assembly, and their independent political base in the corporation has enabled them occasionally to question and criticize mayoral leadership. The corporation and the borough have not, however, been in opposition on fundamental issues of North Slope development. As noted earlier, the borough has favored petroleum development onshore and in nearshore areas and, like the borough, the ASRC has had direct and indirect financial interests in these developments. 
Only in a few cases of proposed offshore exploration have the two organizations been on opposing sides of oil development issues. The general pattern has been one of the corporation and the borough supporting each other's interests, and not only on most matters of oil development. For example, the corporation has supported the borough's subsistence and other cultural programs, and the borough has directed contracts for supplies and services to the ASRC as well as to the village corporation "wards" of the ASRC.

Instead of opposition or countervailing power, then, the relationship between the corporation and the borough has been one of institutional rivalry, which has been expressed largely within the ordered political environment of the borough assembly. Whatever limited effect this institutional rivalry has had in checking concentrated power in North Slope Borough government may have been reduced even further as a result of the 1990 mayoral election. Jeslie Kaleak, corporate secretary of the ASRC, defeated three other candidates who were borough officials, including the capital improvements program director, who ran a close second to Kaleak. Political power on the North Slope may now be further consolidated through the office of the mayor whose incumbent has close ties to the ASRC and to leaders of the borough assembly who are also officers of the corporation.

Apart from the uncertainties and the finite life of the North Slope oil economy itself, the principal external check on the borough is Alaska state government. The state legislature determines, and the administration interprets and applies, the basic rules under which local governments can tax and regulate. Where large-scale resource wealth is involved, one might expect state government to impose limits on local government action. After initially resisting borough incorporation, however, state government has mostly accommodated rather than checked the fiscal appetite of the North Slope Borough. The legislature, for example, has raised the property tax cap that it imposed shortly after the borough's incorporation, while the governor has accepted the borough's claims to higher resident population counts (including Prudhoe Bay workers) which, through a tax formula, increase allowable property tax revenues.

State government accommodated the North Slope Borough primarily because there was enough petroleum wealth in Alaska in the 1980s to accommodate all of the state's regions. Another important factor has been the reluctance of Native leaders in other rural regions to object to the North Slope Borough's capturing a disproportionate (in terms of population) share 
of the wealth. Their reasoning may be that if the North Slope people were not the main beneficiaries, the benefits of greater state taxation of North Slope oil property would not necessarily accrue to their own or other Native regions.

Neither the villages, the Arctic Slope Regional Corporation, nor the state have been significant checks on North Slope Borough government. The oil companies, after initially challenging the borough's incorporation and its tax powers in the courts, have avoided further confrontations with the borough. Thus, the most important check on North Slope Borough government at the beginning of the 1990s is the limited life of the North Slope oil fields and the uncertainties about their future development and value.

\section{CONCLUSION}

The North Slope Borough has been the instrument by which the Inupiat of the North Slope have captured and used the oil wealth in their region. In these terms, the borough has been a success. In order to help assure this success, borough leaders centralized power and authority in the office of the mayor. This made it possible for them to deal more effectively with the external interests--state and federal governments and the oil companies--who also had vital interests in North Slope oil development. Moreover, concentration of borough decisionmaking powers facilitated the high-stakes deals necessary to finance and carry out a billion-dollar capital construction program with the help of an array of consultants, bond underwriters, and contractors.

The economic and political benefits to the North Slope Inupiat are clear. They have gained high levels of local public services, jobs, and incomes. They also have borough leaders who have represented them effectively in negotiations with external corporate and government authorities in matters of oil development, environmental protection, whale harvests, and other conflicts over claims to arctic resources. The borough, itself a central agent of change on the North Slope, has also helped through a variety of programs to preserve and adapt critical elements of traditional Inupiat culture. Finally, the borough has been led and controlled mainly by Inupiats, and this measure of self-government may be one of the borough's most important contributions to North Slope development. 
The costs of development and change under North Slope Borough leadership are apparent, too. The magnitude and pace of the capital construction program resulted not only in waste and inefficiency but also crime and corruption. The financial scandal undermined at least the general perception of responsible self-government on the North Slope. Further, a consequence of centralizing power in borough headquarters was to make the villages into organizational appendages of the borough and to turn borough citizens into clients and consumers. The borough strengthened its power base for dealing with external interests, and it channeled public activity into a fast-paced public works construction program, at the expense of self-determination and public participation in the villages.

A critical and problematic aspect of North Slope Borough government is its cultural preservation programs. Through its large and well-financed administration, the borough has organized and sponsored subsistence activities, programs for elders, traditional festivals, language programs, and other events. These borough programs may well have helped preserve and revitalize Inupiat culture, but possibly at the risk of detaching and transforming some elements of traditional culture into official, borough-sanctioned forms. Although these cultural adaptations are especially difficult to assess, they may be the most significant outcome of North Slope Borough government for Inupiat welfare in the long term.

North Slope Borough government has provided the Alaska arctic Inupiat with means to greater political self-sufficiency. Overall, we believe that the North Slope Borough has responded effectively, under great pressure, to the opportunities and the problems that petroleum development has brought to the region. Borough leaders have had to reach a series of difficult compromises between conflicting claims of petroleum development and environmental protection, traditional culture and western institutions, and regional power and village self-government. Both the accomplishments and the mistakes of nearly two decades of borough government are primarily theirs, which suggests a measure of self-determination that is unusual in rural Alaska and among indigenous northern peoples generally.

Resource wealth has brought the residents of the North Slope Borough relative economic prosperity. However, it has not brought economic independence. The borough villages' economies remain almost totally dependent on tax revenues from the oil industries, in which they have minimal direct participation. Other industries have not developed in the villages which 
might eventually replace the oil industry as an economic base. The North Slope Borough experience suggests that even highly favorable conditions of Native self-determination together with control of substantial resource wealth do not necessarily result in sustainable economic independence for northern Natives.

The North Slope oil property tax base will eventually erode as oil production declines. The question is what will be the consequence for the borough and for North Slope villagers who have depended so heavily upon borough resources. That is essentially the same question that was asked about the borough a decade ago. A more critical question for the next decade and beyond may be whether the experience of having been supported by a prosperous borough government for more than a generation will leave the North Slope Inupiat prepared for the challenges that are yet to come.

\section{ACKNOWLEDGEMENT}

Preparation of this article was supported in part by the U.S. Department of the Interior, Minerals Management Service, Social and Economic Studies Program, which has funded extensive research on North Slope Borough communities as well as other rural areas of Alaska. All conclusions are those of the authors. 


\section{REFERENCES}

Arnold, R.D. 1976. Alaska Native land claims. Anchorage, Alaska Native Foundation.

Associated Press. 1984. New North Slope mayor hopes to curb borough spending. Anchorage Daily News, 5 October.

Case, D.S. 1989. Subsistence and self-determination: can Alaska Natives have a more "effective voice"? University of Colorado Law Review 60 (4): 1009-1035.

Chance, N.A. 1990. The Inupiat and Arctic Alaska. Fort Worth, Holt, Rinehart and Winston.

Department of Community and Regional Affairs, State of Alaska. 1990. Alaska Taxable 1989.

Impact Assessment, Inc. 1990. Northern institutional profile analysis: Beaufort Sea. Social and Economic Studies Program Technical Report No. 142. Anchorage, U.S. Department of the Interior, Minerals Management Service.

Knapp, G. and Nebesky, W. 1983. Economic and demographic systems analysis, North Slope Borough. Social and Economic Studies Program Technical Report No. 142. Anchorage, U.S. Department of the Interior, Minerals Management Service.

Kruse, J. 1990. Alaska Inupiat subsistence and wage employment patterns: understanding individual choice. Draft manuscript. Anchorage, Institute of Social and Economic Research, University of Alaska Anchorage.

Mauer, R. 1990. Bribe verdicts wring out last of North Slope's dirty laundry. Anchorage Daily News, 22 September.

McBeath, G.A. 1981. North Slope Borough government and policymaking. Man in the Arctic Program Monograph No. 3., Fairbanks, Institute of Social and Economic Research, University of Alaska.

Morehouse, T.A. and Leask, L. 1980. Alaska's North Slope Borough: oil, money and Eskimo self-government. Polar Record 20(124): 19-29.

Morehouse, T.A., McBeath, G.A. and Leask, L. 1984. Alaska's urban and rural governments. Lanham, Maryland, University Press of America.

Morehouse, T.A. and Leask, L. 1978. Governance in the Beaufort Sea Region: petroleum development and the North Slope Borough. Springfield, Virginia, National Technical Information Service. Alaska OCS Studies Program (Technical Report No. 16). 
Nebesky, W.E. 1989. North Slope Borough Census of Population and Economy. Final Report. Barrow, Alaska, North Slope Borough, Department of Planning and Community Services.

North Slope Borough. 1983. A Message to All Alaskans. Advertising insert in Alaska newspapers. August.

North Slope Borough. 1987. Comprehensive Annual Financial Report. Fiscal Year 1986, Barrow, Alaska.

North Slope Borough. 1990. Comprehensive Annual Financial Report. Fiscal Year 1989. Barrow, Alaska.

Osherenko, G. 1987. Sharing power with Native users: co-management regimes for Arctic wildlife. Photocopy. Wolcott, Vermont, The Center for Northern Studies.

U.S. Department of Commerce, Bureau of the Census. 1980. 1980 Census Tape STF1 printouts, on file at the Institute of Social and Economic Research, University of Alaska Anchorage. 